\title{
Democratic Experience in Central Europe: 25 Years Later ${ }^{i}$
}

\author{
Jerzy J. Wiatr \\ Department of Social Sciences, European School of Law and Administration, Poland
}

Copyright $\bigcirc 2017$ by authors, all rights reserved. Authors agree that this article remains permanently open access under the terms of the Creative Commons Attribution License 4.0 International License

\begin{abstract}
Democratization of the formerly communist states of Central Europe took place during the "third wave of democratization" (Huntington). It was a remarkably orderly process, resulting in the establishment and consolidation of new democratic systems. In this respect Central Europe, mostly because of its cultural identity as part of the Western civilization, differed positively from most of the former Soviet republics and from the Balkans. Recently, however, new authoritarian regimes, based on free election but abolishing the rule of law, have been established in Hungary and Poland, mostly due to the dissatisfaction of the poorer strata with the effects of system transformation.
\end{abstract}

Keywords Authoritarianism, Democracy, Democratization, Election, Parties, Rule of Law

\section{The Third Wave of Democratization: Hopes and Worries}

In late 1980s and early 1990s the collapse of Communist regimes in Europe attracted the attention of scholars who tried to predict the future and to identify the main challenges facing the countries in the process of transition. Samuel P. Huntington's comparative study of democratization initiated the discussion on the prospects of democracy in the countries of transition, stressing the uncertain character of this process(1). In the discussion that followed, the crucial question was the likelihood of the successful establishment and consolidation of the democratic regimes. Huntington predicted the possibility of the third reverse wave, which like the earlier retreats - would bring the collapse of new democracies at least in some countries under transition. His main argument was historical. Post-communist states have had a history of undemocratic regimes prior to the establishment of the communist regimes and in most of them the dominant political cultures showed strong authoritarian characteristics. Therefore, Huntington argued, there was a high likelihood that history would repeat itself.
In his later study, Huntington emphasized the importance of political cultures (2). His crucial concept of "civilization" is based mostly on the religious heritage and its impact on political cultures. In reference to Europe, Huntington stressed the fundamental difference between two Christian civilizations: Eastern and Western. The line dividing them runs along the eastern borders of Finland, Estonia, Latvia, Lithuania, Poland, Slovakia, Hungary, and Croatia countries which because of their history and religion belong to the West Christian civilization.

Political cultures in Huntingtonian sense are important because the great religious schism that divided Christianity in the eleventh century had profound consequences for the relations between rulers and its subjects. The subordination of the Orthodox Church to the secular power of emperors (originally of the Eastern Roman empire, and later of the Russian Tsars) led to the omnipotence of the state vis-à-vis its subjects. In the West, however, the position of the Church was much stronger. Conflicts between the monarchs and the popes provided West European nobility relatively greater protection of its rights that it was the case in the East. In this sense, history has shaped the political cultures of two parts of the European continent.

Political culture approach the interpretation of different patterns of democratization has been applied by several students of political change in post-communist states. Klaus von Beyme stresses the delayed and complicated process of creating democratic political cultures and considers it the main factor making the long-term effects of transformation in the post-communist states uncertain (3). In my comparative analysis of democratization in post-communist Europe I stressed the importance of political cultures and institutional choices as the main explanatory factors accounting for the difference between Central Europe and the post-soviet republics (4)

A different caveat was formulated in the comparative study of "East South System Transformation", which focused on the comparative analysis of early transformation in Latin America, Asia, Southern and Eastern Europe (5). Scholars involved in this study saw the main danger in the socio-economic tensions resulting from the radical 
transformation of economic systems in formerly communist states. The same concern was voiced by the group of researchers organized by late Rudolf Wildenmann (6). Having been involved in both studies I have raised the same worry (7). It was a concern shared by several authors, particularly by Juan Linz and Alfred Stepan, who -in the comparative study of democratic transformation in three different regions - pointed to the particularly difficult situation in the post-communist states, where political change had to be combined with the socio-economic transformation from "command economy" to free market (8). With the passing of time it became clear that in spite of growing economic and social inequalities as well as a temporary decline of the standard of living in all post-communist states, the resulting tensions have not destroyed the new democratic systems. In several cases, the second free elections brought to power left-wing parties with their roots in the reforming wing of the formerly ruling communist parties (Lithuania in 1992, Poland in 1993, Hungary in 1994). When in power, these parties continued the policy of democratic transformation. The communist counter-revolution has not materialized. At the end of the twentieth century the Hungarian political scientist Attila Agh presented the Central European transformation as the success story (9).

It does not mean, however, that all worries voiced in the first years of transformation withered away. After twenty five years, we can compare these early worries with the experience of a large group of twenty-nine post-communist states in Europe.

The picture is mixed. In 2013, the Freedom House rated 13 of them (45\%) as "fully free", $9(31 \%)$ as "partly free", and 7 $(24 \%)$ as "not free". Compared to other regions of the world, the post-communist states were closed to the world average, but lagged behind Western Europe and Latin America.

The most interesting aspect of the Freedom House comparison is the division of post-communist states in terms of the relative success or failure of democracy. The category of fully free states contained exclusively states which had not been parts of the Soviet Union before the second world war (Bulgaria, Croatia, Czech Republic, Estonia, Hungary, Latvia, Lithuania, Montenegro, Poland, Rumania, Serbia, Slovakia and Slovenia). Eleven of them were members of the European Union and of the North Atlantic Treaty Organization. The top five (with the maximum ratings in both democratic rights and citizen freedoms) were the Central European states: Czech Republic, Estonia, Lithuania, Poland and Slovenia.

The "partly free" category included a mix of post-Soviet and East European states: Albania, Armenia, Bosnia and Herzegovina, Georgia, Kirgyzstan, Kosovo, Macedonia, Moldavia, and Ukraine. This category included, therefore, some of the post-soviet republics as well as some of the formerly Yugoslav ones (plus Albania, which shares some social characteristics with the southern parts of former Yugoslavia.
The third category ("not fee") is exclusively composed by the formerly Soviet republics: Azerbejdjan, Belarus, Kazakhstan, Russia, Tajikistan, Turkmenistan and Uzbekistan.

The taxonomy presented by Freedom House corresponds closely to the findings of the cross-national study on "Democracy and Local Governance", which in the years 1991-2001 covered 28 countries, including 15 post-communist states. Data from this study (provided by the national coordinator Krzysztof Ostrowski) showed differences between local political leaders in the level of their respective support for values of political equality, political pluralism and respect for the rights of minorities. In six of the states under investigation local leaders demonstrated their positive attitudes to the democratic values. This category included local leaders from the Czech Republic, Poland, Hungary, Slovakia, Lithuania and Slovenia (in this order of relative acceptance of democratic values). In eight, the leaders scored negatively. This category included: Ukraine, Armenia, Latvia, Russia, Belarus, Kazakhstan, Uzbekistan and Kirgistan (in the growing order of negative responses to the questions on democratic values). In Estonia, local leaders occupied a middle place between support for and rejection of the democratic values.

\section{Why Democracies Won, Why They Failed?}

These findings lead to two main conclusions.

First, the level of economic development partly explains the relative success or failure of democracy, but should be aware of deviant cases. The most interesting of them is Montenegro - one of the poorest states of Europe, which has been characterized as fully democratic.

Second, the type of the political system chosen in the first years of transition, had a strong impact on the prospects of democracy. The parliamentary type of political system proved to be a much safer choice than the presidential one, as predicted by Fred Riggs in his analysis of the prospects of new democracies (10).

Third, the heritage of history seems to be the crucial factor. There are two main aspects of this relationship. First, countries which are now in the category of fully democratic have had at least some experience with democratic form of government prior to the establishment of the communist rule. Second, the length of time of the existence of the communist regime emerges as the single most important variable. All states which have been placed in the "not free" category have been under communist rule since the victory of Soviet communists in the civil war of 1918-21. In the category of "fully free" states none was communist before the Second World War. The difference of time lived under the communist regime is important for at least two reasons. One is the composition of political elites. In old post-Soviet republics communist regime lasted for more than seventy 
years which made it impossible for members of the elite to be recruited from among those who had been active in politics before the establishment of the communist system. In East-Central Europe, on the other hand, prominent role was played by people who had had some earlier political experience from the times before the communist rule. The other consequence of this difference is the degree to which communist indoctrination affected the mentality of the society. Russian studies of this aspect conducted by the team of political scientists and sociologist from Moscow State University under the leadership of Elena Shestopal, demonstrate the importance of this historical factor (11).

What remains to be explained is the status of Central Europe within the broader category of post-communist states. Central Europe can be defined in historical cultural terms as the group of countries which belong to the Western civilization (in terms of Huntington's meaning of civilization) and became communist during and because of the Second World War. In none of them communists came to power on their own. Their political victory resulted from the Soviet political and military hegemony. Some of the countries of Central Europe showed a remarkable strong opposition to the communist rule and/or strong reformist tendencies within the ruling communist parties: most notably Hungary in 1956, Czechoslovakia in 1968, and Poland in 1956 and again in 1980/81. The collapse of the communist regimes in Europe began in Central Europe with the Polish negotiated compromise between regime and the democratic opposition in the Spring of 1989, the Czechoslovak "velvet revolution" of November 1989, and the Hungarian fully democratic election in March of 1990. In the very real sense, Central Europe was the leader of democratization in the communist bloc.

\section{Authoritarianism - Old and New}

Twenty five years later, the picture is much less clear. There have been authoritarian and populist tendencies in several states where democracy had been established on the ashes of the communist regimes. Hungary, and recently Poland can now be placed in the category of "illiberal democracies" to use a rather ambiguous term suggested by Fareedd Zakaria (12). Similar tendencies have been present, although in weaker forms, in Slovakia. Pessimists believe that we are facing now a wave of new authoritarianism in Central Europe.

New authoritarianism is a mixed system of government, in which competitive elections and political pluralism still exist, but the rule of law has been destroyed by the executive branch of government and the party in power successfully control most of the media. The emergence of new authoritarianism in those post-communist states, which from the outset failed to establish democratic system of government, is easy to explain in terms of their history and political culture. The emergence of such regimes in some of the states, which twenty five years ago were the front-runners of democratization, is more complicated.

To understand what happened in Hungary and what is taking place in Poland, one has to take into account the main weaknesses of the democratic politics of these countries. In elections which brought to power authoritarian parties in Hungary (2010) and Poland (2015), the key accusations raised against their predecessors (socialist in Hungary, liberal in Poland) were socio-economic. The key issue was economic inequality and corruption.

Economic inequality in Central Europe is not particularly high, if compared with other regions of the world - except Western Europe. The Gini coefficient for the Central European countries was as follows (data mostly from 2012; exceptions put in brackets): Czech Republic, Croatia 32.0 (2011), Hungary 30.6 (2007), Estonia 33.2, Latvia 35.5\%, Lithuania 33.2\%, Poland 32.4, Slovakia 26.1, Slovenia 25.6. Some post-communist states from outside Central Europe scored much higher: notably Russia (41.6 I 2012) and Macedonia (43.2 in 2009). It is not the absolute level of inequality what causes frustration in Central Europe but the fact, that after almost half of century under remarkably egalitarian social policies of the previous regimes citizens of the Central European states are particularly sensitive to economic inequalities. Moreover, sociological studies on the perception of social inequality show that egalitarian sentiments become stronger when the economic situation deteriorates. It is, therefore, logical that the slowing of economic growth, resulting from the world financial crisis of 2008 , the saliency of inequalities became increased.

The issue of corruption is even more puzzling. According to "Transparency International" the perceived level of corruption in Central Europe was moderately high, with Poland showing greater sensitivity to this issue than the other countries of the region. Of 176 countries under study, Poland ranked $38^{\text {th }}$, Hungary $46^{\text {th }}$, Czech Republic $57^{\text {th }}$ and Slovakia $61^{\text {st }}$ in the ranking, in which perception of corruption is negatively related to the score. Is corruption in Poland more flagrant than in the other countries of the region? Or is the negative picture of corruption in Poland the result of the extensive use of the corruption issue in the electoral campaign of 2015 ?

For explaining the rise of the populist tendencies in Central European politics the crucial question is the perception of inequalities and of corruption. In politics, things are what they are believed to be. The political campaigns launched by the populist parties have been successful because a considerable part of voters accepted their narration.

For twenty five years politics in Central Europe was dominated by political elites which came to power in the early stages of the transition and were mostly composed of the leaders of the democratic opposition and reformists from the former regime. Their political background makes than different from the ruling Russian elite, which has shown a marked continuity with the Soviet political elite from the 
latest period of the communist rule(13) In biological terms they were still perfectly capable of functioning in high level politics for several more years, but in psychological terms they have already lost their ability to lead. In stable conditions, when no major political change takes place, leaders continue to serve for decades. The situation is markedly different in periods of rapid change, like the ones which have been taking place in post-communist states. Time is running faster and citizens expect new people to lead. The need for elite rotation has been unequally manifest in the Central European countries. In Poland, stability of the "old elite", which had been in power since 1989 (with very short intervals in 1992 and again in 2005-2007), gave ammunition to the "Law and Justice" party's campaign for change. A similar process had taken place in Hungary, where the old (socialist and liberal-democratic elite) was replaced by people whose first entries in politics took place within the youth movement ("Fides").

Predicting future is a risky business, but I am inclined to risk the prediction that the authoritarian turn in Central Europe is a passing phenomenon. Hungary may become a deviant case, because of the particularly strong position of the "Fides" and the magnitude of its electoral support (combined with the deep crisis of the traditional center-left parties). There are similar tendencies in other countries of the region, but not strong enough to bring about new authoritarian regimes.

Poland will be the crucial test case. The intensity of internal conflict and the emergence of citizens' movement in opposition to the new government suggest that the rule of "Law and Justice" will not be very long. Crucial will be the provincial and local elections 2018 and the parliamentary election of 2019. However, even if - as I predict - the ruling party loses, things will not return to the status quo ante. The encounter with populism will force the mainstream political parties to reassess their policies and to look for new solutions.

\section{Notes}

(1) Samuel P. Huntington (1991), The Third Wave: Democratization in the Late Twentieth Century, Norman \& London: University of Oklahoma Press

(2) Samuel P. Huntington (1996), The Clash of Civilizations and the Remaking of the World Order, New York: Simon \& Schuster

(3) Klaus von Beyme (1996), Transition to Democracy in Eastern Europe, London \& New York: Macmillan \& St. Martin's Press

(4) Jerzy J. Wiatr (2008), "Democratizations in Central Europe: Comparative Perspectives" in: Jose V. Ciprut, ed., Democratizations: Comparisons, Confrontations, and Contrasts, Cambridge \& London: The MIT Press, pp. $145-164$
(5) Adam Przeworski et al. (1995), Sustainable Democracy, Cambridge: Cambridge University Press

(6) Egbert Jahn and Rudolf Wildenmann, eds. (1995), Stability in Eastern Europe?, Baden-Baden: Nomos Verlangsgesellschaft

(7) Jerzy J. Wiatr (1995), "Democracy versus New Authoritarianism in eastern Europe", in: Richard Kilminster and Ian Varcoe, eds., Culture, Modernity, and Revolution. Essays in honour of Zygmunt Bauman, London\& New York: Routledge, pp. 201-214

(8) Juan Linz and Alfred Stepan (1996). Problems of Democratic Transformation and Consolidation: Southern Europe, South America, and Post-Communist Europe, Ba;timore \& London: The Johns Hopkins University Press

(9) Attila Agh (1998), The Politics of Central Europe, Beverly Hills\% London: Sage Publications

(10) Fred Riggs (1988), "The Survival of Presidentialims in America: Para-Constitutional Practices", International Political Science Review, vol. 9.no.4, pp.248-274

(11) Elena Shestopal, ed. (2016), New Trends in Russian Political Mentality, Lanham: Lexington Book

(12) Fareed Zakaria (2007). The Furure of Freedom: Illiberal Democracy at Home and Abroad, New York: W.W. Norton

(13) David Lane and Cameron Ross (1999), The Transition from Communism to Capitalism: Ruling Elites from Gorbachev to Yeltsin, New York: St. Martin's Press, p. 205

\section{REFERENCES}

[1] Agh Attila (1998), The Politics of Central Europe, Beverly Hills \& London: Sage Publications

[2] Beyme Klaus von (1996), Transition to Democracy in Eastern Europe, London\& New York: MacMillan Press \& St.Martin's Press

[3] Huntington Samuel P. (1991), The Third Wave: Democratization in the Late Twentieth Century, Norman \& London: University of Oklahoma Press

[4] Huntington Samuel P. (1996), The Clash of Civilizations and the Remaking of World Order, New York: Simon \& Schuster

[5] Jahn Egbert and Wildenmann Rudolf, eds. (1995), Stability in East Central Europe?, Baden-Baden: Nomos Verlagsgesellschaft

[6] Lane and Ross (1999), The Transition from Communism to Capitalism: Ruling Elites from Gorbachev to Yelstsin, New York: St. Martin's Press

[7] Linz Juan J. and Alfred Stepan (1996), Problems of Democratic Transition and Consolidation: Southern Europe. South America and Post-Communist Europe, Baltimore \& London: The Johns Hopkins University Press 
[8] Przeworski Adam et al (1995), Sustainable Democracy, Cambridge: Cambridge University Press

[9] Riggs Fred W. (1988), "The Survival of Presidentialism in America: Para-Constitutional Practices", International Political Science Review, vol.9, no.4, p.247-278

[10] Shestopal Elena, ed. (2016), New Trends in Russian Political Mentality, Lanham: Lexington Books

i Paper was presented at the XXIV Congress of the International Politica Science Association, Poznan 2016 [on the panel on "Central Europe in the Global Context" organized jointly by IPSA Research Committee 47 and by the Central European Political Science Association]. The author is Professor Emeritus of the University of Warsaw and honorary rector of the European School of Law and Administration in Warsaw. He served as vice-president of IPSA (1979-82) and as president of CEPSA (2000-2003).
[11] Wiatr Jerzy J. (1995), "Democracy versus a New Authoritarianism in Eastern Europe" in: Richard Kilminster and Ian Varcoe, eds., Culture, Modernity and Revolution: Essays in Honour of Zygmunt Bauman, London \& New York: Routlege, p.201-214

[12] Wiatr Jerzy J. (2008), "Democratizations in Central Europe: Comparative Perspectives, in: Jose V. Ciprut, ed., Democratizations: Comparisons, Confrontations, and Contrasts, Cambridge \& London: The MIT Press, pp. 145-164

[13] Zakaria Fareed (2007), The Future of Freedom: Illiberal Democracy at Home and Abroad, New York: W.W. Norton 